\title{
The vegetation cover of New Zealand during the Last Glacial Maximum: Do pollen records under-represent woody vegetation?
}

\author{
Matt S. McGlone \\ Landcare Research, Lincoln, New Zealand \\ mcglonem@landcareresearch.co.nz
}

Rewi M. Newnham

School of Geography, Environment \& Earth Sciences, Victoria University of Wellington, Wellington, New Zealand

\section{Neville T. Moar}

Research Associate, Landcare Research, Lincoln, New Zealand

\section{Introduction}

The Last Glacial Maximum (LGM) was a global event characterised by cool, often dry climates, low atmospheric $\mathrm{CO}_{2}$ concentrations, low sea level and high ice volume, with polar and mountain glaciers and ice sheets at their maximum extent in most regions. The most widely used definition of its duration is $18 \mathrm{ka}$ to $24 \mathrm{ka}$ ( $\mathrm{ka}=1000$ calendar years before present), suggested by Mix et al. (2001). Newnham et al. (2007) have demonstrated that this is not appropriate for New Zealand (and almost certainly globally) and have proposed an extended LGM of c. 29 ka to c. $19 \mathrm{ka}$, which definition we will use here. The LGM is of key importance in understanding how the global climate system functions and a considerable effort over recent decades has been put into generating and collating datasets that document how components of the ocean-land-atmosphere system reacted during this period. One of these components is vegetative cover, important because it integrates diverse climatic drivers over wide areas. In this paper, 'trees' refers to woody plants that regularly achieve $\geq 6 \mathrm{~m}$ in height, and 'shrubs' to woody plants $<6 \mathrm{~m}$.

The vegetative cover of New Zealand during the LGM has been assessed largely from pollen evidence. These records have been interpreted as showing extensive non-forest communities (scablands, grassland, shrublands) in the southern North Island and the South Island, with continuous and extensive forest tracts mostly confined to the North Island north of $38^{\circ} \mathrm{S}$ 
(Newnham et al. 1999). Nevertheless, on the basis of pollen, macrofossil and biogeographic evidence, it has been hypothesised that most forest trees and shrubs typical of a given region survived in situ, albeit mainly in small stands (McGlone 1985).

Recently, this interpretation of the LGM landscape has been challenged. Beetle evidence, it is claimed, shows that closed, woody vegetation was more extensive than indicated by pollen records at low to mid-altitudes in the south of New Zealand (Burge and Shulmeister 2007) and that at times the LGM environment was much warmer and wetter, and very much more woody than hitherto suspected (Marra et al. 2006; Woodward and Shulmeister 2007). Burge and Shulmeister (2007:130) suggest the time has come to reassess the situation:

'More important than any temperature inference is the observation that the current interpretation of glacial-age vegetation from pollen data appears not to be robust. There are now a number of studies ... that demonstrate that local site indicators from around New Zealand suggest woody vegetation persisting through glacial times. A variety of mechanisms have been proposed by the authors so that these differing records can be reconciled to the pollen-based interpretation of glacial vegetation. Our site clearly indicates that there is at least as good a case to reinterpret the pollen information.'

To summarise, they argue that interpretations of pollen records have consistently underestimated the extent of LGM forest or closed woody vegetation. Thus, the issue is not whether forest trees and shrubs survived, but the extent of forest or closed woody vegetation cover during the LGM and the consequent implications for vegetation and climate reconstruction.

This review critically examines this claim that LGM pollen records are systematically under-representing forest and woody vegetation, as suggested from the beetle evidence. We also consider plant macrofossils, as they provide independent evidence. This reassessment of pollen and macrofossil evidence indicates that there is at least as good a case to reinterpret the beetle conclusions.

\section{Pollen representation of LGM vegetation}

Here, we present two sorts of pollen evidence. First, we assess the general pattern of pollen distribution during the LGM by using selected, single pollen samples from a wide geographic spread of sites; and second, we look in more detail at several representative sites which cover all, or significant proportions, of the LGM chron. The widespread Kawakawa Tephra (c. $27 \mathrm{ka}$ ) from a large ignimbrite eruption of the central North Island is an important marker horizon for this study (Pillans et al. 1991), as is the Rerewhakaaitu Tephra (c. $17.6 \mathrm{ka}$ ) (Newnham et al. 2003). In all the pollen diagrams presented, pollen percentages have been calculated from a pollen sum which includes all terrestrial pollen types, but excludes ferns, wetland graminoids and forbs and the wetland shrub Leptospermum. The term Fuscospora refers to Nothofagus subgenus Fuscospora beeches. Locations mentioned in the text are shown in Figure 1.

In Figure 2, we present the pollen and spore spectra from 60 pollen-analysed sites dating to the LGM. Where the site pollen record contains more than one pollen sample dated to the LGM, the sample with least arboreal pollen was chosen so that the minimum extent of forest pollen presence is depicted. We therefore refer to this as the minimum forest LGM dataset. As the climates of the LGM period were variable (Newnham et al. 2007), and contamination of ${ }^{14} \mathrm{C}$ samples with younger carbon a greater problem in that time range than later, a pollen 'snap- 

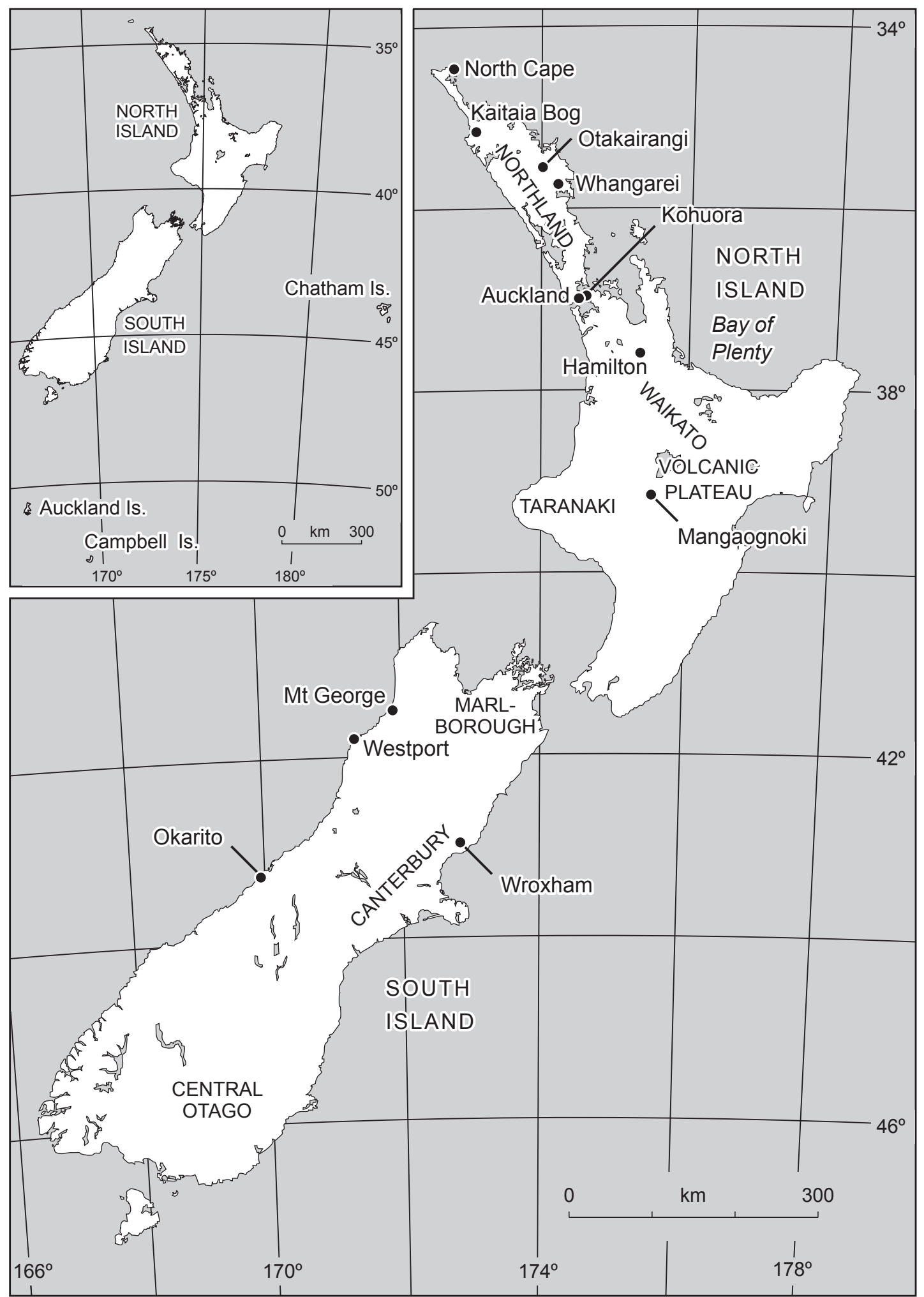

Figure 1. New Zealand region, showing locations mentioned in the text

shot' approach introduces uncertainty. At most of the shorter sequence sites, we are uncertain whether LGM interstadial or stadial conditions are represented. Examples of this variation within the LGM can be seen in the representative pollen diagrams shown in Figure 3. It should also be noted that temporal variation in forest cover within the LGM may explain some of the 


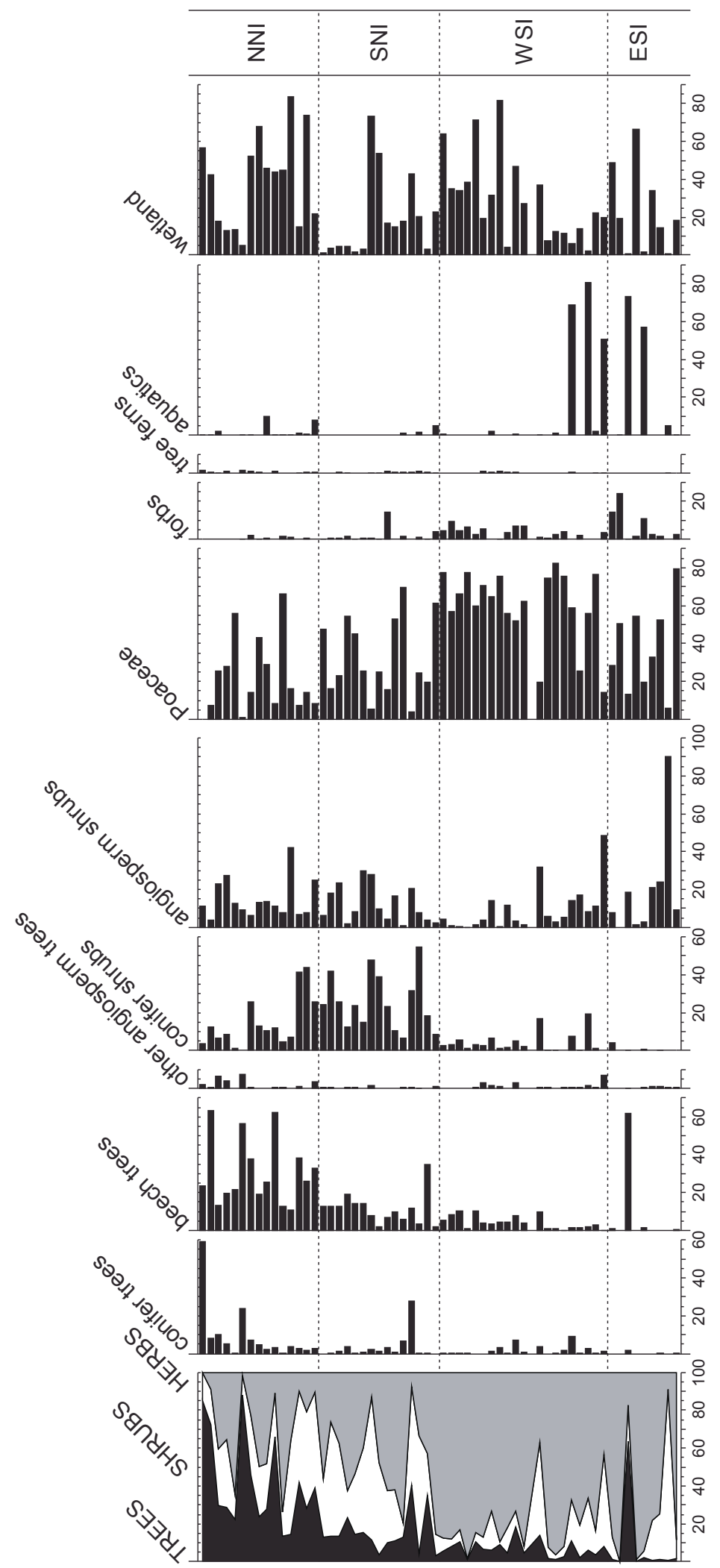

Figure 2. Pollen and spore results for selected forest minimum samples, LGM. Arranged in order of increasing latitude within broad zones: northern North Island (NNI - north of latitude $37^{\circ} \mathrm{S}$ ); southern North Island (SNI - south of $37^{\circ} \mathrm{S}$ but including the Nelson district); western South Island (WSI - south of Nelson, west of the Main Divide); eastern South Island (ESI - south of Nelson, east of the Main Divide). Pollen sum: all terrestrial types excluding ferns, lycopods and wetland forbs, rushes and sedges 
a) Otakairangi, Northland

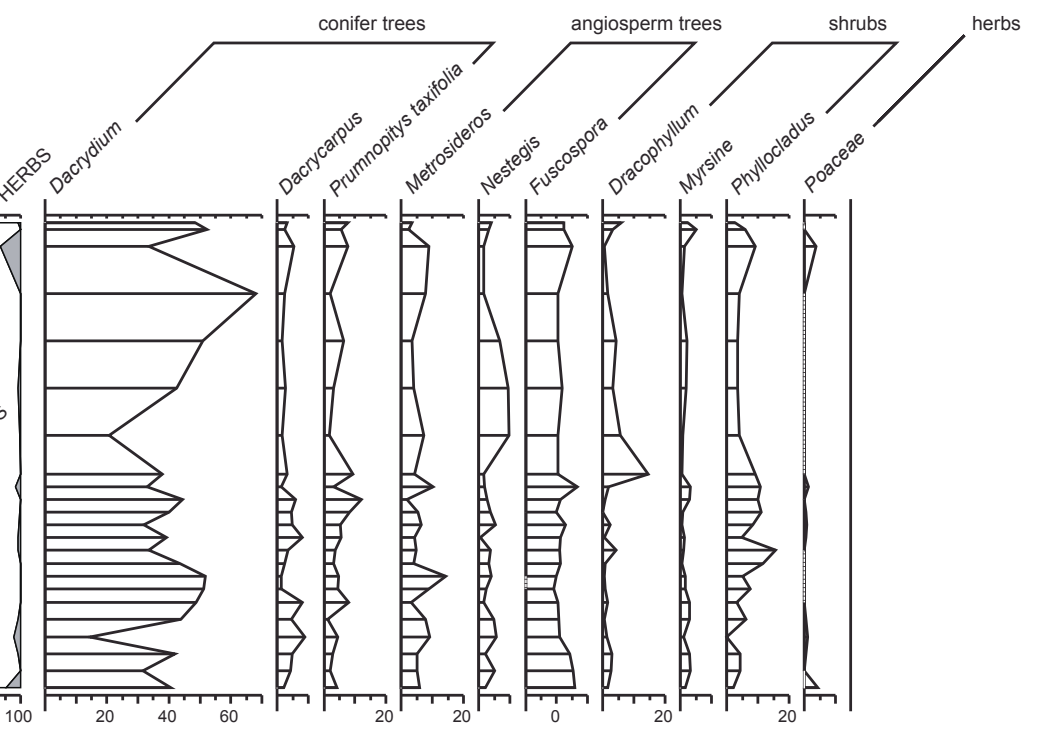

b) Kohuora, Auckland
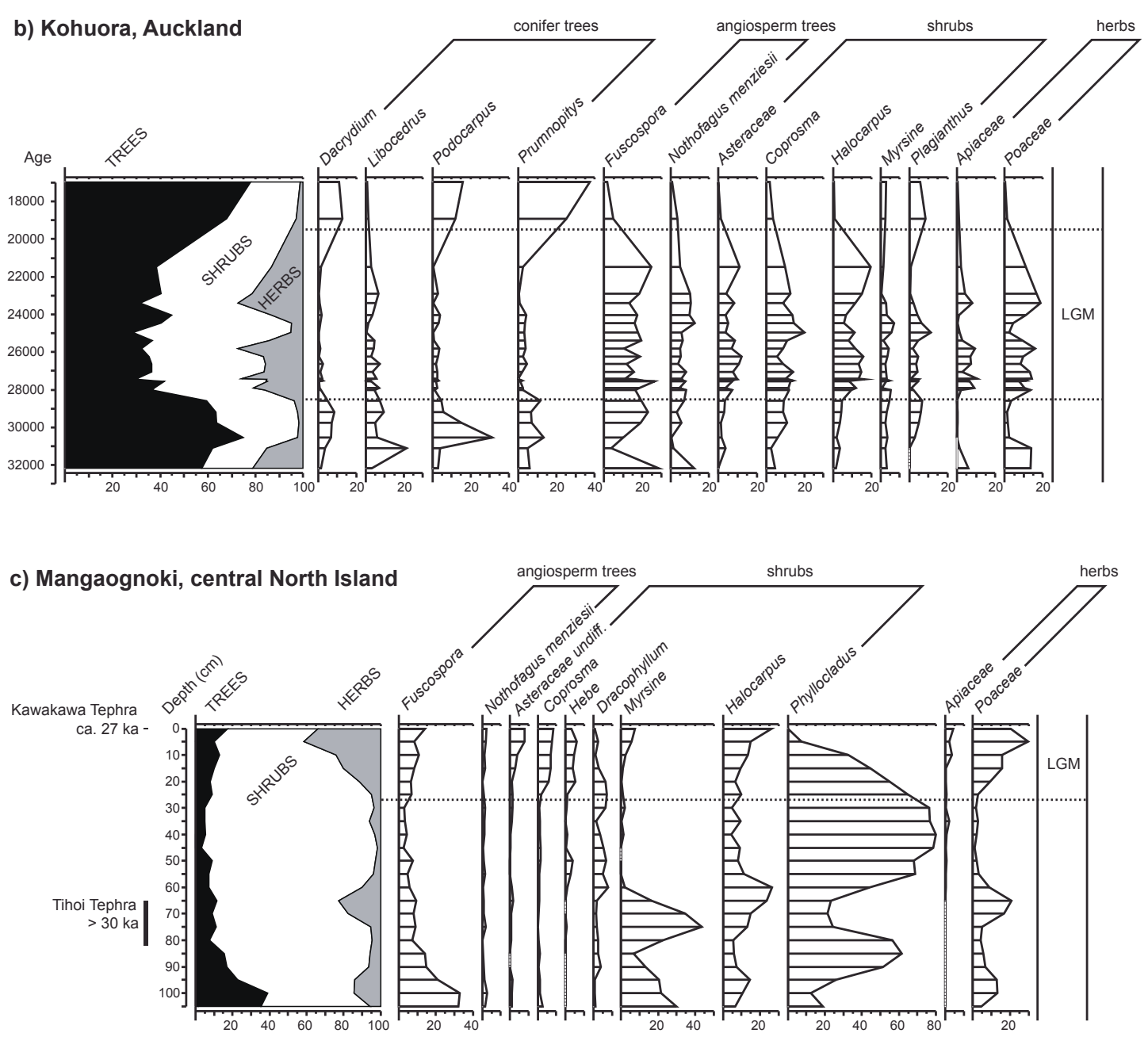

Figure 3. Representative pollen diagrams covering part or most of the LGM chron for: Northland (a) northern North Island (b), central North Island (c), western South Island (Figure 3 continues on page 54) 
d) Okarito, Westland

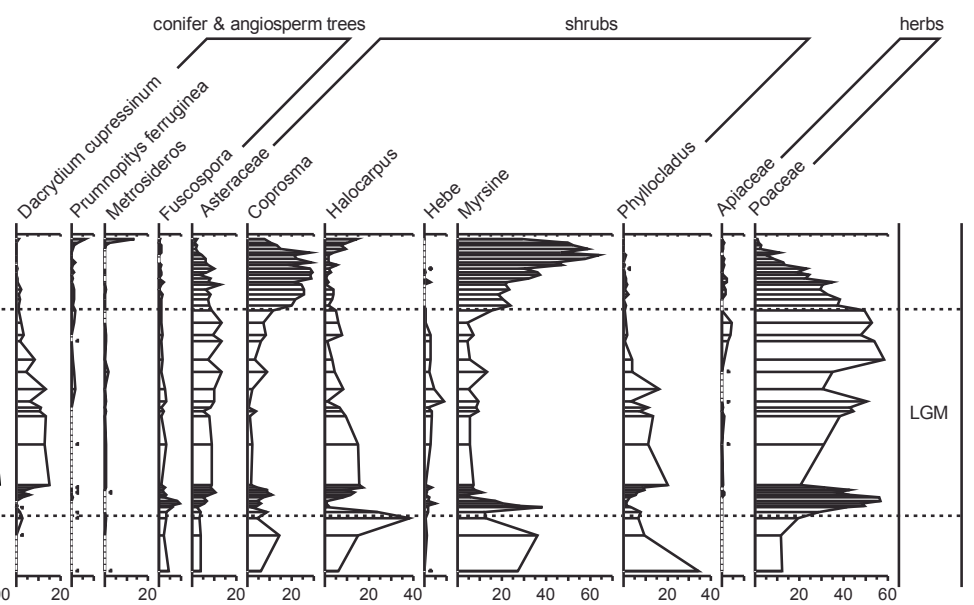

e) Wroxham, Canterbury

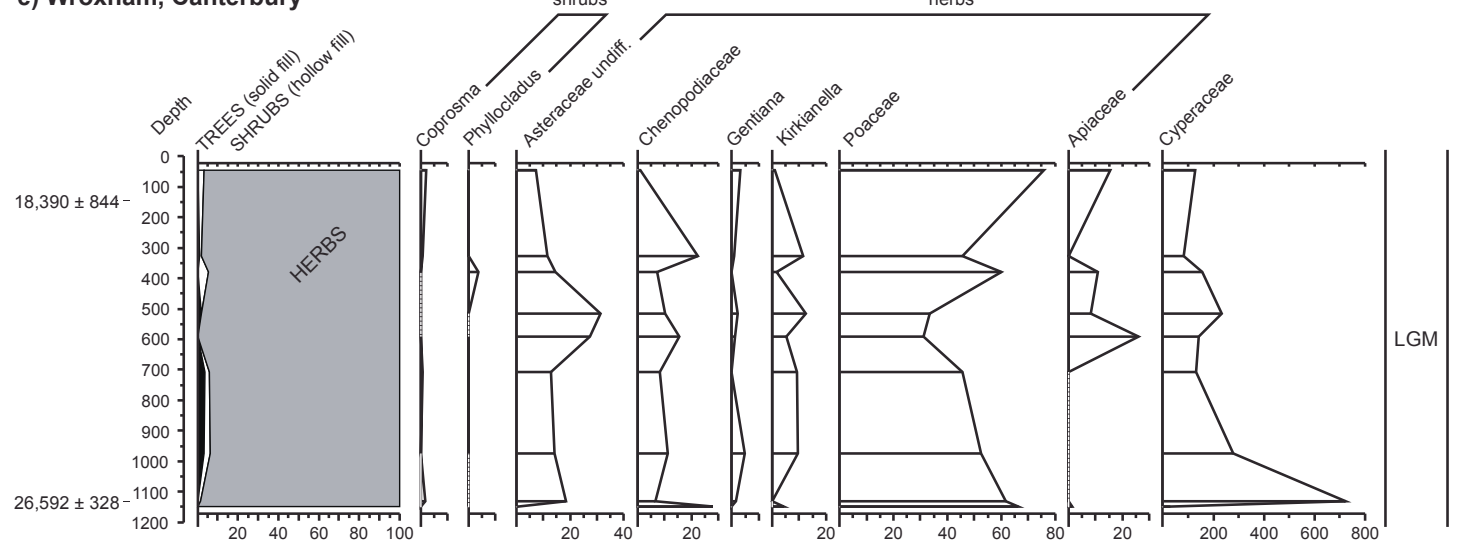

Figure 3. (cont.) Representative pollen diagrams covering part or most of the LGM chron for: Northland (d), and eastern South Island (e). Pollen sum as for Figure 1. All ages are in cal yr BP

differences reported between palaeoecological sequences, particularly when different sites and different proxies are compared (Newnham et al. 2007).

It is not possible to be too choosy about site characteristics for LGM pollen spectra if a broad coverage is wanted. The LGM pollen sample sites form a highly heterogeneous set, including lake and pond deposits, peats, organic-rich soils, and thin organic silts enclosed in gravel or loess matrices. Most are likely to have been derived from soils or relatively shortlived ponds or peaty backwaters in aggrading fluvial channels. Even those from a relatively small number of lakes or peat bogs tend to have been deposited during times of inorganic sedimentation within the basin.

The composition and source area of a given pollen sample is strongly affected by local site characteristics. Peats and soils usually are dominated by pollen and spores of vegetation growing within a few metres of the collection point. The degree to which they also sample the regional pollen rain depends on the local vegetation. Soils beneath forest stands generally record little other than the trees immediately in the vicinity; peats or soils with a low or herbaceous vegetation cover will adequately record pollen from surrounding dryland vegetation. Fens, lakes and ponds not only receive pollen rain from aerial dispersal of pollen from the wider surrounding region, but obtain a variable amount of water-transported pollen and spores. The relative source area of ponds and lakes depends on the size of their basin: the smaller they are, the larger the amount of pollen derived from immediately adjacent vegetation; the larger, the more regional and extra-regional pollen sources are represented (Sugita 1994). Marine sediments (not included in this terrestrial dataset) receive some pollen from direct deposition 
on the sea surface, but much must come from fluvial transport. Inevitably, some of the pollen is reworked from non-contemporaneous deposits. Transport along waterways and settling over weeks through the water column enriches the spectra in some pollen and spore types (e.g. fern spores, winged pollen such as that of many conifers, and reworked fossil types; McGlone 2001a). Marine-core pollen is good at recording long-term fluctuations in pollen and spore input, but poor at sensing details of the onshore vegetation, and thus we use it only as an adjunct.

\section{Geographic pattern of pollen and spore representation during the LGM}

The main feature of the minimum forest LGM pollen and spore assemblages is the low percentages of tree pollen and the high levels of non-woody pollen types (Poaceae, Asteraceae, forbs) (Figure 2). The mean for forest tree pollen over all sites is $15.1 \pm 18 \%$ and only 14 sites $(23 \%)$ have more than $25 \%$ forest tree pollen. Tree ferns form a particularly low component of the total $(0.7 \pm 1.1 \%)$ and conifer trees make up $2.8 \pm 7.2 \%$, while $88 \%$ of all the forest pollen recorded is of Nothofagus. This is a strong contrast with modern late-Holocene pre-deforestation assemblages (135 sites distributed throughout New Zealand; Wilmshurst et al. 2007), which average c. $80 \%$ tree pollen from conifer (c. $44 \%$ ) or angiosperm (c. $35 \%$ ) sources, c. $7 \%$ from tree ferns, and low amounts from herbaceous (c. $4 \%$ ) or shrub (c. 17\%) sources.

Turning to regional distinctions, some broad patterns are evident. Four northern sites suggest a nearly complete forest cover north of Auckland at the LGM. Dodson et al. (1988) report a podocarp-hardwood forest similar to that of the present at North Cape (34.5 $\mathrm{S}$ ); Fuscospora-conifer-hardwood forests dominated at Kaitaia Bog (35० S; Elliot 1998), near Whangarei (35.5 S; Newnham 1992) and coastal Waikato (37.5 S; Lees et al. 1998). Analysis of the pore number of the Fuscospora pollen type suggests Nothofagus truncata was the major pollen contributor at these northern sites (Lees et al. 1998; Newnham 1992), consistent with its status as the major Fuscospora species of the northern North Island at present. A solitary South Island site (Mount George; Moar et al. 2008) is also dominated by forest, largely Fuscospora and Nothofagus menziesii. The Mount George site is distinctive in that it is close to the LGM shoreline on the flanks of a steep coastal range, exactly the type of site long predicted as being the only place where extensive forest tracts could persist in the south.

The northern LGM pollen spectra can be easily matched with those from extant forests far to the south or at higher altitudes. In general, similar pollen spectra characterise the lowland western South Island at present.

We now exclude the five largely forested sites in order to characterise the extensive partially forested landscapes (Figure 4). Leaving aside Northland, LGM New Zealand can usefully be split into four regions: Auckland, Bay of Plenty and the Waikato Basin (NNI); the Volcanic Plateau southwards to northern Marlborough (SNI); the South Island west of the glaciers (WSI); and the eastern South Island (ESI). Tree pollen shows a decline from north to south and west to east: NNI 41\%; SNI 15\%; WSI 7\%; and ESI 4\%. Its variability is high in NNI, but much lower further south. Shrub conifers are abundant in NNI and, in particular, SNI, making up c. $17 \%$ and $26 \%$ respectively of the pollen rain. Grass, other shrubs and forbs increase from north to south, collectively averaging $88 \%$ in WSI and $98 \%$ in ESI.

LGM pollen records from the Auckland Isthmus (Figure 3b; Newnham et al. 2007) depict a landscape in which forest, largely dominated by Fuscospora, Nothofagus menziesii, Libocedrus and Phyllocladus, forms a mosaic with shrubland and grassland. Although there are some traces of typically northern species (e.g. Agathis australis), arboreal species which later become common in the postglacial and Holocene are at low levels or absent (e.g. Metrosideros, Cyathea, Nestegis) (Lancashire et al. 2002; Sandiford et al. 2003). Similar pollen spectra occur further south in the North Island and a cluster of sites in the Hamilton Basin are close in composition to those from the Auckland Isthmus (Newnham et al. 1989). We do not have LGM records 


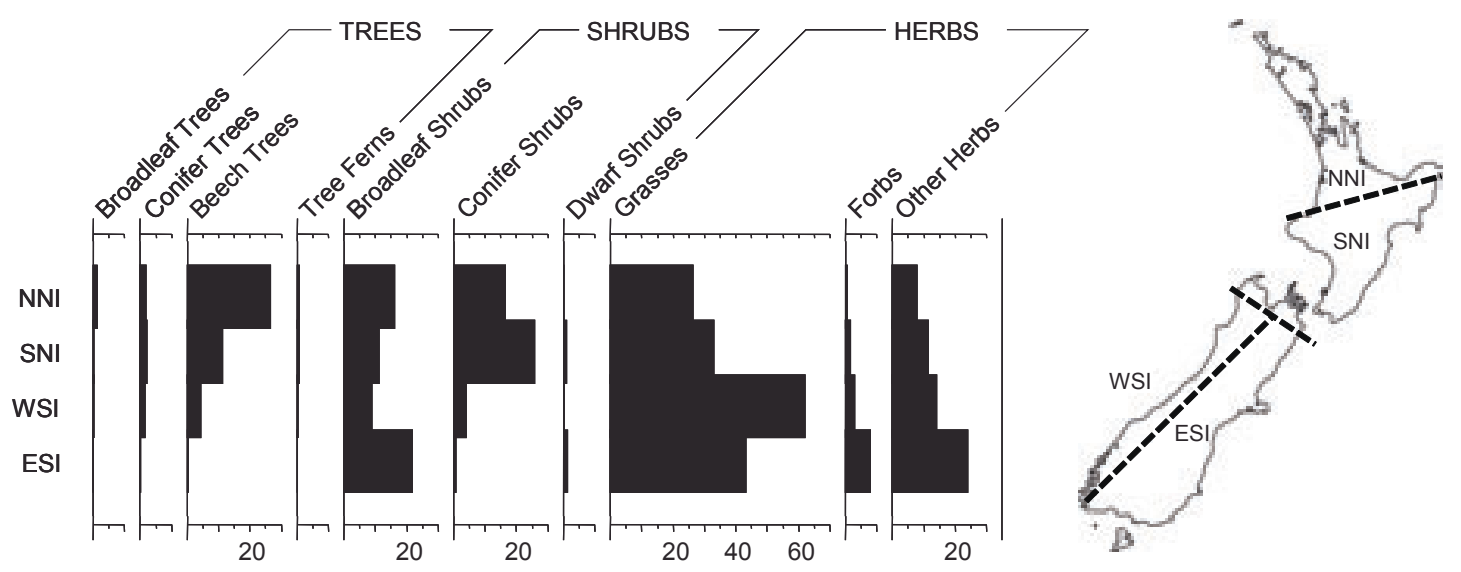

Figure 4. Summary pollen averaged for NNI, SNI, WSI and ESI LGM vegetation zones

from coastal Bay of Plenty in the east, but pollen records for the interstadial immediately preceding indicate Nothofagus-conifer forest, conifer shrubland and grassland mosaics with more forest but otherwise similar to those prevailing in the Auckland Isthmus (McGlone et al. 1984). Nothofagus, conifer shrubland and grass-dominated pollen assemblages are recorded at sites up to $800 \mathrm{~m}$ on the Volcanic Plateau (Figure 3c; McGlone and Topping 1983). The Fuscospora percentages are relatively consistent across the altitudinal gradient, suggesting derivation from scattered stands, while high, variable percentages of grass, conifer shrubs and other shrub types are consistent with local shrubland/grassland mosaics. Lowland Taranaki sites at current sea level have repeatedly experienced shrub and grass-dominated intervals, with low tree-pollen percentages during the last glaciation (McGlone et al. 1984), and the two LGM sites at current sea level are dominated by conifer shrubs, other shrubs and grassland (McGlone 1980).

Although the Auckland Isthmus, Waikato Basin, Volcanic Plateau, Bay of Plenty and southwestern North Island pollen sites range over $800 \mathrm{~m}$ of altitude and $4^{\circ}$ of latitude, they all record much the same sort of open shrub and grassland-dominated vegetation with a greater or lesser forest component (Figure 2). Tree percentages are generally less than $50 \%$ and dominated by Fuscospora, Nothofagus menziesii and Libocedrus. While forest types are more abundant and tall conifer and hardwood elements more commonly encountered in lower altitude and latitude sites, there is no clear zonation with successive dominance by lowland forest, montane, shrubland and grassland with increasing altitude, as might be expected from comparison with present-day zonations. Moreover, there is a great deal of variability in the non-arboreal representation: grass pollen has a mean of $40.8 \% \pm 26.4 \%$ and ranges from $7.5 \%$ to $67.4 \%$. The general pollen and spore composition of a number of these sites (particularly those of the Waikato Basin) is close to that of modern and Holocene sites from the inland eastern South Island, which was partially forested with tall conifer shrubs before deforestation (McGlone and Moar 1998).

It has been long noted that in the central North Island, areas above $600 \mathrm{~m}$ to $800 \mathrm{~m}$ lack tephra older than the early postglacial, and this is consistent with a lowering of the treeline by about $800 \mathrm{~m} \pm 100 \mathrm{~m}$, as predicted from LGM glaciers on the Tongariro Mountains (Pillans et al. 1991). The presence of extensive grassland and shrubland at present-day sea level must have resulted from other factors than depression of mean annual temperatures (McGlone 1985).

WSI pollen spectra differ most noticeably from SNI spectra in their lower amounts of shrub conifer (4\% versus $26 \%$ ) and much greater amounts of grass and forb pollen $(71 \%$ versus $44 \%)$. However, despite this indication of lower stature and more open vegetation, there are sites in this region with high tree-pollen levels (c. 10\%; mainly Dacrydium cupressinum, Prumnopitys, Fuscospora and Nothofagus menziesii. Metrosideros (likely to be M. umbellata) is 
more common in this region than anywhere else). Inland sites close to the LGM ice margin tend to have very high levels of grass pollen and low levels of shrubs (Moar 1980).

Only a few LGM sites have been analysed from the eastern South Island (Figures 2 and $3 e)$. Their most distinctive feature is the paucity of tree or shrub-conifer pollen $(1.4 \pm 1.5 \%$; minimum $0 \%$, maximum $4.9 \%$ ). This is almost exactly the same percentage as recorded by modern pollen sites on subantarctic Campbell Island, some $600 \mathrm{~km}$ south of the New Zealand mainland (McGlone and Meurk 2000). The LGM pollen spectra are dominated by Asteraceae and grasses and have a range of low-growing forbs. Common herbaceous elements such as the Lactuceae (dandelion group), Chenopodium, Brassicaceae and Rumex indicate open herb and dwarf shrub communities similar to those found today in riverbeds or saline Central Otago terraces (Moar 1980).

In summary, LGM pollen spectra indicate forest survival throughout New Zealand, even at times of 'minimum forest', with a general trend of greater forest reduction towards the south and east.

\section{Do interpretations of LGM pollen data underestimate the extent of woody vegetation?}

The argument that pollen data under-represents the abundance of woody and arboreal vegetation during the New Zealand LGM is not a replay of the debates that have raged in Europe over pollen interpretations of the LGM. In Europe, LGM pollen records have been interpreted by some as supporting a treeless landscape north of the Alps, with comparatively moderate percentages of tree pollen attributed to reworking or long-distance dispersal, whereas more recently, the same pollen records are being aligned with macrofossil and genetic evidence suggesting forest survival in northern 'cryptic refugia'. By contrast, New Zealand pollen analysts have been consistent in claiming forest and shrubland was present throughout most of New Zealand during the LGM, despite the dominance of southern pollen sites by non-arboreal pollen and spores and very low representation of tree pollen in some sites (Figure 2). Indeed, it is relevant to note that a recent review of the glacial refugia debate in Europe acknowledged that New Zealand pollen analysts were the first to propose micro-refugia for trees during LGM times (Bennett and Provan 2008). In particular, McGlone (1985:731) demonstrated that evidence for postglacial spread from discrete northern LGM refugia was weak and that universal survival of all plants in the regions they currently occupied was a viable hypothesis:

'The conclusion which can be drawn from the suddenness with which forest reoccupied the landscape, and the lack of migratory waves or extended successions, is that podocarp-hardwood forest was close to nearly every site yet investigated. Survival of some forest throughout New Zealand has been proposed on biogeographic grounds, particularly as regards the Nothofagus species which are reputedly slow movers.... If Podocarpus spicatus and Ascarina lucida could survive the glacial maximum in the southern regions of New Zealand, there is every reason to suppose that nearly all other southern trees and shrubs could also. It therefore seems that this model of widespread survival of forest trees can be expanded to cover nearly every plant at present resident within a region.'

Thus, New Zealand pollen records have long been interpreted as showing forest-shrubgrassland mosaic with local survival of core regional species in small patches.

This interpretation is corroborated by plant macrofossil evidence. Wood, stems, leaves and seeds of forest trees are uncommon in LGM sediments south of the Auckland Isthmus - that is, from areas where pollen evidence shows trees were likely to have been scarce or patchy. 
Nothofagus menziesii and Nothofagus cliffortioides leaves and twigs have been reported from sites in north Westland (Moar and Suggate 1996; Turney et al. 2002; Marra and Leschen 2004), but there are no other reports. Many kilometres of exposures of alluvial silts and gravels dating to the LGM period are known, and in the south, they are barren of wood. In the central North Island, three major ignimbrite eruptions, the Kawakawa Tephra $(27,097 \pm 957 \mathrm{cal} \mathrm{yr}$ BP), the Okareka Tephra $(21,800 \pm 500 \mathrm{cal} \mathrm{yr} \mathrm{BP})$ and the Rerewhaakaaitu Tephra $(17,625 \pm$ 425 cal yr BP; all ages from Lowe et al. 2008) covered many square kilometres of landscape, but tree charcoal and wood associated with these deposits is uncommon. This relative absence of tree macrofossils cannot be attributed to preservational artefacts. Wood, charcoal and leaves of forest trees are common in late glacial and Holocene alluvial sediments (Molloy et al. 1963; Pullar and Patel 1972) and post-LGM ignimbrites close to source tend to have charcoal and charred wood associated with them. Moreover, macrofossils of shrubs (including conifer shrubs) and herbs are often encountered in LGM sediments (for instance, McGlone et al. 1978; Soons and Burrows 1978; Neall 1979; McGlone and Topping 1983), thus confirming the presence of suitable sites for preservation. There have been a number of isolated reports of macrofossils from LGM pollen sites, but detailed studies are rare. Soons and Burrows (1978) report on a rich macrofossil LGM site in inland Canterbury at an altitude of $780 \mathrm{~m}$, which was dominated by herbaceous or prostrate woody vegetation, with a complete absence of shrub or tree macrofossils. Together with information from pollen in the same sediments, it is clear that sparse, herb-dominated vegetation occupied the site.

As pollen evidence clearly points to the presence of forest, albeit in limited amounts, throughout non-glaciated regions, and recent beetle evidence (Marra and Leschen 2004; Burge and Shulmeister 2007) shows that trees were growing in inland eastern South Island locations, the near absence of woody plant macrofossils is significant. Absence of tree wood or other macrofossils can probably be explained by two factors. Wood of forest trees normally becomes preserved in alluvial deposits because of undercutting of river banks or slips in steep catchments and subsequent transport by water and then rapid, deep burial by aggregating silt and gravel deposits. This is a common depositional context for LGM deposits containing macrofossils. For example, in a recent investigation of plant macrofossils from sites extending across Eurasia, Binney et al. (2009) report that all 45 samples of trees dated to the LGM (25-17 kyr cal BP) are from sites located in or near a river floodplain, whereas for samples younger than $15 \mathrm{ka}$, all types of landscape position are represented in the samples. In New Zealand, if LGM forest tree stands were both much rarer than now, and mainly growing on protected, stable sites, they would have had a much smaller chance of being incorporated in the alluvial deposits from which most of our information comes. Such stable sites are also unlikely to preserve soil charcoal, as charcoal is normally preserved by soil movement after burning (Wardle 2001).

In Figure 5, we summarise the vegetation cover of New Zealand during the coolest phases of the LGM based on our interpretation of biological and physical evidence.

\section{Can we reconcile pollen and beetle evidence?}

Burge and Shulmeister (2007) claim that beetle fossils indicate much more closed woody vegetation than pollen evidence would suggest. This claim relies primarily on their beetle fossil sites in the Westport area (coastal northwestern South Island), which they say demonstrate the close-by presence of closed canopy woodland, while the pollen interpretation (Moar and Suggate 1979) is of an open grassland with a woody element. Clearly, this is a critical site for resolving the problem.

We note that in the beetle faunas from this site classic wet-forest saproxylic taxa like Pycnomerus and other zopherids, for example, are completely absent from this sequence, 


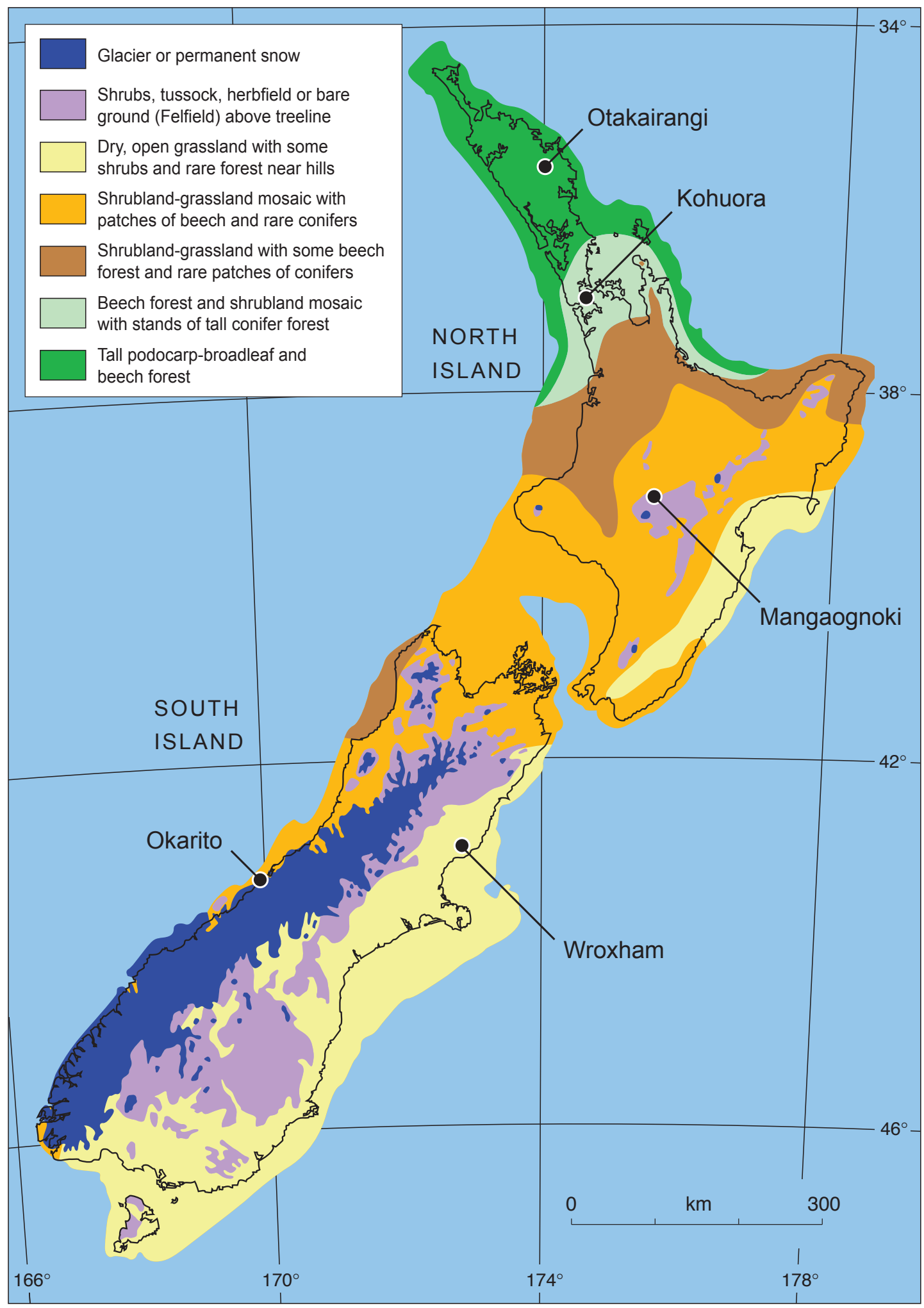

Figure 5. New Zealand vegetation cover at the height of the LGM as reconstructed from pollen, macrofossil, beetle and geomorphic evidence 
except for a single sample towards the base (and potentially pre-LGM). The remaining taxa are not necessarily obligates of closed canopies, but almost certainly would be well suited to woody vegetation of many structures (Nick Porch pers comm. 2009). We note that the pollen percentages at this site typically have c. $30 \%$ tree and shrub pollen, thus indicating near-local presence of some woody vegetation. Instead, Burge and Shulmeister (2007) propose 'The contrast between the pollen and beetle reconstructions may thus simply represent a combination of an enlarged pollen-collection area and low pollen-producing taxa (including arboreal taxa) being overshadowed by abundant input from increased areas of grassland and local wetland taxa such as Myriophyllum and Cyperaceae' (p 129). At this particular site, Myriophyllum and Cyperaceae did not affect the pollen sum in this way. Aquatics are by convention not included inside the pollen sum (that is, are not part of the percentage calculation) and when Cyperaceae, which were included by Moar and Suggate (1979), are excluded, there is still a substantial pollen sum of c. 150 grains. For the interval dated to the LGM $(18,650 \pm 250$ ${ }^{14} \mathrm{C}$ yr BP; $162 \mathrm{~cm}$ ), $6 \%$ of the pollen is from trees, $26 \%$ from shrubs and $67 \%$ from grass, a little higher than, but similar to, the original publication figures. Excluded wetland types make up only about a third of the total terrestrial and wetland pollen sum, a similar level to that found at modern pollen sites surrounded by forest, grassland or shrub (McGlone 1982; McGlone and Moar 1997). There are traces of under-represented pollen types such as Hebe and Dracophyllum. These pollen results therefore suggest a grassland-shrubland in the vicinity of the site, or a grassland-dominant site with a woody element, as per the interpretation in Moar and Suggate (1979). The simplest explanation for the apparent discrepancy between beetles and pollen is that there isn't one.

At a more general level, there is little reason to believe that dominant shrubland and forest could remain essentially invisible in terms of plant fossils across the LGM landscape. Small stands of wind-pollinated trees or shrubs within grassland communities are not underrepresented in the present landscape. About $20 \%$ of pollen from modern sites from grassland in central Canterbury inter-montane basins derives from stands of Nothofagus, essentially in the same proportion as its regional coverage (Randall 1990). On the other hand, trees and shrubs with poorly dispersed pollen are less likely to be represented if they are even a few tens of metres from a site (e.g. Leptospermum, Weinmannia racemosa). If the woody vegetation of the LGM consisted almost entirely of plants with poor pollen dispersal, it is possible that it could be massively under-represented in the pollen rain. However, woody vegetation dominated by such plants is rather rare in the current vegetation (an exception being the subantarctic islands, which we discuss below). Shrubland taxa, including wind-pollinated types such as Coprosma and insect-pollinated types such as Muehlenbeckia and Myrsine, are very well represented in late-glacial transitions (e.g. McGlone and Neall 1994; Newnham, Vandergoes et al. 2007). Unless there was a major shift in the woody taxa that characterised shrubland during the LGM, for instance from Hebe or Dracophyllum, to better-represented shrub types, the late-glacial transition experienced a rapid increase in woody vegetation cover. This, in turn, implies that during the LGM, New Zealand had a much larger representation of herbaceous vegetation. However, if we make the assumption the LGM woody cover was largely of these more cryptic taxa, what would we expect the pollen representation to have been? Fortunately, we have a close analogy in subantarctic Campbell Island, a small island of some $113 \mathrm{~km}^{2}, 600$ $\mathrm{km}$ south of the New Zealand mainland (Figure 1).

In general terms, the LGM pollen rain in the western North and South Islands, is similar to that of subantantarctic Campbell Island today. About two-thirds of Campbell Island is in herbaceous vegetation and the major shrubland dominants both in size and abundance are Dracophyllum spp. Low Dracophyllum forest-tall shrubland, which dominates the sheltered eastern side of the island, gives way with altitude to Dracophyllum/Myrsine/Coprosma shrubland, tussockland and tundra herbfield. A total of 46 pollen sites have been used to characterise the modern pollen rain (McGlone and Meurk 2000). Grass pollen makes up 
$37 \% \pm 26 \%$ of the terrestrial pollen rain, and shrubs $27 \% \pm 26 \%$. As we estimate Campbell Island grassland and woody cover to be approximately a third each, these results suggest that pollen fairly represents the vegetation. Although the dominant woody element, Dracophyllum spp, is under-represented in mainland sites (McGlone 1982), this is not so apparent on Campbell Island (McGlone and Meurk 2000), largely due to the complete absence of tall, wind-pollinated trees and shrubs. Short-statured vegetation does not contribute much to the regional pollen rain, as pollen released near ground level is less likely to be lofted into the air stream and typically is transported only a short distance. Therefore, poorly dispersed local pollen sources will not be diluted (as percentages) by extra-local well-dispersed pollen sources. The 13 Campbell Island sites classified as grassland or megaphyllous forb/grassland had a mean herbaceous pollen percentage of $69 \% \pm 20 \%$, of which grass pollen comprises $65 \% \pm 23 \%$, with a shrub contribution of $6 \% \pm 4 \%$. Grass percentages ranged from $27 \%$ to $96 \%$, similar to those of southern South Island sites in the minimum forest LGM dataset.

The analogy between subantarctic Campbell Island and LGM southern New Zealand is not exact: the subantarctic islands have extensive peatlands which were rare during the LGM, and the pollen rain has considerable amounts of ground fern spores $(62 \% \pm 55 \%$; outside pollen sum), much higher than southern LGM New Zealand (10\% $\pm 54 \%)$. Nevertheless, the LGM pollen match is much closer to Campbell Island than to present-day or Holocene pollen mainland assemblages. For instance, the Ahukawakawa Swamp, an extensive wetland-grassland complex on the flanks of Mount Taranaki, although recording much grass and wetland pollen, generally had $50 \%$ or more woody pollen types (McGlone et al. 1988). In fact, extensive modern-day pollen sampling in New Zealand rarely has identified indigenous vegetation sites that yield more than $50 \%$ grass pollen, the exceptions being induced indigenous or exotic lowland grasslands (Randall 1990; McGlone 2001b). The minimum forest LGM sites regularly exceed this value, and average roughly this amount in WSI and ESI.

Our preferred explanation for dominance by herbaceous pollen during the LGM, therefore, is that the pollen spectra more or less proportionally represent broad vegetation cover classes. However, for completeness, we will consider two possible alternative explanations.

1) Low atmospheric concentrations of $\mathrm{CO}_{2}$ at the LGM may have led to comparatively less pollen production by woody plants which must invest in carbon-rich support structures. There is some evidence that pollen production diminishes with low $\mathrm{CO}_{2}$ (Ladeau and Clark 2006; Rogers et al. 2006). However, as described above, forest persisted in the north throughout the LGM and forest pollen increased sharply in North Island sites around 18,000 years ago (Newnham et al. 2003), several thousand years before there was any significant increase in atmospheric $\mathrm{CO}_{2}$ concentration. Similarly, a mid-LGM warming and period of forest expansion evident in some NZ pollen records (Vandergoes et al. 2005; Alloway et al. 2007; Newnham, Vandergoes et al. 2007) coincides with minimum atmospheric $\mathrm{CO}_{2}$ concentration. If there was a $\mathrm{CO}_{2}$ effect on flowering, it certainly was insufficient to prevent adequate forest pollen representation.

2) Sites that preserve LGM pollen spectra may have been more likely to be in grassland. LGM peatlands are rare (McGlone 2009), and many LGM pollen sites are temporary ponds and sloughs, often associated with valley bottoms or in terrace deposits associated with gravels or inorganic sediments. These low-lying situations, often subject to frequent sediment deposition, flooding and erosion, and hard winter frosts, thus may have favoured grassland. Nevertheless, modern pollen evidence strongly suggests that small pockets of grassland in stable shrub or forest-covered landscapes are not dominated by grassland pollen. Moreover, many sites are stable and not in topographic depressions. The Westland site where the beetle and pollen evidence is apparently in 
conflict accumulated organic silts over more than 10,000 years, and thus was not unstable, although dominated by grassland pollen types (Moar and Suggate 1979), and nor were the Auckland Isthmus or Volcanic Plateau sites (McGlone and Topping 1983; Newnham, Lowe et al. 2007). Certainly, much of the variability in the pollen results from the LGM derives from the topographic position of the sites but, rather than distorting the picture, is probably a fairly faithful representation of the actual distribution of unstable terrain.

It seems clear that during the LGM, woody vegetation, although common, ceded dominance to herbaceous communities and bare ground over much of New Zealand south of Northland. In the inland and eastern South Island, woody vegetation of any sort was quite limited. Forest trees, although present throughout, made up such a low proportion of the vegetative cover that they contributed little to the pollen rain. Note that this does not imply large regions without trees, as our preferred model is scattered stands of trees or patches of forest throughout. As tree pollen is the dominant component of long-distance pollen transport, absence of this pollen source automatically increases the percentage representation of local vegetation cover relative to the situation during the Holocene. This percentage effect is not necessarily misleading if the local vegetation fairly represents the broader landscape. With regard to this issue, there is some possibility of under-representation of low-growing shrubs interspersed with, or forming extensive patches within, grassland. For instance, the Rotoaira Basin site on the Volcanic Plateau, central North Island, has more grass and less shrub pollen represented than the contemporaneous nearby sites on rolling hill country (McGlone and Topping 1983). However, the same interpretation would be taken from both sets of sites: extensive grassland and shrub cover.

Although the attribution of beetle fossils to closed woody vegetation or litter under closed woody vegetation (Marra and Leschen 2004; Burge and Shulmeister 2007) seems well founded, there is little specificity in the attributions and no basis for conclusions about plant abundance. According to the brief descriptions given, most of the beetles could persist under any sort of woody vegetation. Of the tall trees, only Nothofagus has been identified from its fossil beetle fauna (Marra and Leschen 2004). We note that there is little published ecology on New Zealand beetles, and the basis for most of the conclusions about fossil assemblages is sparse notes attached to specimens or appended to morphological descriptions in faunas. No modern survey of present-day beetle remains in relation to their current environment has been undertaken in New Zealand, and thus basic facts (for instance, how well the local vegetation is reflected in the fossil fauna; from what distance the beetles may have come) are simply unknown. If there were a more diverse and abundant beetle fauna on woody vegetation relative to grassland plants, or if beetles inhabiting woody vegetation were more likely to become fossils, the inferences made on the basis of beetles would be misleading. We contrast this situation with the well-documented and quantified information on modern pollenvegetation relationships in New Zealand.

\section{Causation of the pattern of LGM vegetation in New Zealand}

The essential problem in interpreting the LGM vegetation cover of New Zealand is that the depression in mean annual temperatures does not in itself explain the substantial reduction in forest cover indicated by pollen and macrofossil records. On the basis of glacial features and reconstructions of sea-surface temperatures derived from marine cores off southern New Zealand, mean annual temperatures fell during the LGM by only $4-5^{\circ} \mathrm{C}$ (Pelejero et al. 2006; Barrows et al. 2007). Note that no land temperature adjustment for lower sea level is necessary (as erroneously suggested by many), as the atmospheric mass above any terrestrial point was 
unaffected by falling sea levels due to compensatory storage of water as ice on land, while observed sea-surface temperatures should be adjusted down by c. $1^{\circ} \mathrm{C}$ when compared with contemporaneous terrestrial temperatures to account for increased atmospheric mass above the ocean surface (Osmaston 2006). A fall of $5^{\circ} \mathrm{C}$ equates to a lowering of vegetation zones in much of southern New Zealand by c. $800 \mathrm{~m}$, which leaves some 300-400 m in altitude above present sea level for montane forest even during the coldest phases (McGlone and Bathgate 1983). Further north, forest should have been able to dominate up to $700 \mathrm{~m}$ in altitude above present sea level. As we have seen, the pattern of disturbed ground in the central North Island, as indicated by absence of pre-LGM tephras, supports the inference drawn from the pollen that continuous vegetation extended to about this altitude. However, pollen assemblages and plant macrofossils strongly support the concept of low shrubland-grassland being the dominant cover. The question thus becomes one of why forest and tall woody vegetation generally was not more extensive.

As discussed earlier, it is unlikely that forest absence was a direct effect of low atmospheric $\mathrm{CO}_{2}$ concentrations, as forest persisted in the north, and in small patches throughout. On the current landscape, forest and tall woody vegetation is generally excluded below the regional tree line by (1) frequent disturbance including by river channel activity, landslides, storms and fire; (2) low precipitation (under $450 \mathrm{~mm} \cdot \mathrm{a}^{-1}$ ); (3) intense frost, which can exclude Nothofagus, the main montane tree species (Wardle 1985); and (4) persistent wind. While there was undoubtedly a great deal of ground disturbance during the LGM, as evidenced by enhanced aggradation recorded as gravel deposits, loess sheets and high levels of silt in offshore marine cores, it seems improbable that it would have been frequent or widespread enough outside the river and stream flood channels to have permanently repressed tall woody vegetation. Although precipitation is likely to have been lower (Alloway et al. 1992) and to have constrained forest in eastern districts (McGlone 2002a), westerly winds continued to prevail, making it highly unlikely that precipitation could have dropped to levels low enough to restrict forest in western South Island and most North Island districts outside of the southeast. Persistent wind keeps the windward flanks of subantarctic Campbell and Auckland Islands nearly entirely clear of forest and most shrubs (McGlone 2002b), but on mainland New Zealand such strong effects are highly localised on upland ridges and exposed coastal cliffs. If the extraordinarily strong, persistent winds of the subantarctics fail to keep forest and tall woody vegetation from the sheltered sides of those islands, LGM winds were unlikely to have done so on the mainland.

Although all of these factors must have played a role, we are left essentially with outbreaks of very cold, dry air off cold oceans and expanded sea ice to the south as the most probable single explanation for the widespread elimination of forest and tall woody vegetation (McGlone et al. 1993). A similar explanation has been used regarding LGM pollen assemblages in southern Australia (Harle et al. 2004). Tree dormancy is broken and cold resistance is lost in late spring, and freezing events during this period are likely to have been particularly effective in retarding tree growth. Southern Hemisphere plants are particularly susceptible because of their low freezing tolerance (Bannister 2007). The fact that grass-dominated sites occurred from current sea level to $600 \mathrm{~m}$, and from the far south of the South Island to the Auckland Isthmus, provides a strong support for frequent, brief-duration cold events differentially affecting sites because of their topography and latitude. A present-day analogue is the July 1996 Southland frost, during which lowland temperatures fell as low as $-15^{\circ} \mathrm{C}$ and remained well below freezing for more than a week, leading to widespread mortality of indigenous plants, including podocarp trees (Bannister 2003). Considering that the Southland frost occurred during one of the warmest decades of the past century, it seems at least possible that during the LGM, with surrounding seas much cooler, extended Antarctic sea ice closer to the mainland, outbreaks of icebergs to as far north as the Chatham Rise (Carter et al. 2002; Crundwell et al. 2008; Fraser et al. 2009) and extensive glaciers along the axial ranges, similar or longer or more severe outbreaks would be much more common. A recent modelling simulation of New Zealand LGM climate 
showed an increase in the frequency and strength of the southerlies, and showed they were capable of bringing very cold polar air over most of the country, with the east of the South Island especially affected (Drost et al. 2007). As the severity of these southerly incursions would have lessened towards the north, this explanation is consistent with the generally higher levels of forest pollen observed at northern sites in the minimum forest LGM dataset.

\section{Conclusions}

The traditional accounts of an LGM southern landscape in which forest and tall woody vegetation was attenuated towards the south and nearly absent in the southeast of the South Island, and grassland vegetation prominent from the Auckland Isthmus southwards are supported by our analysis. However, the exact proportion of the landscape in either forest or closed woody vegetation is difficult to determine because of the relatively few sites dated to the LGM, and the possibility of bias towards LGM sites either frequently disturbed or subject to cold-air drainage and hence greater-than-normal frost stress. A straightforward reading of the LGM pollen results would suggest that as much as $65 \%$ of the NNI, $55 \%$ of the SNI, $20 \%$ of the WSI and 25\% of the ESI was 'woody' - that is, in either forest or shrubland. It is difficult to see how the current beetle studies can challenge this conclusion, especially given their lack of quantification and modern validation. Instead, they give firm evidence for the presence of shrubs, closed woody vegetation and Nothofagus in the few sites where they have been analysed. If the woody vegetation indicated by beetles equates primarily to montane-subalpine woody vegetation, shown by pollen to be extensive throughout southern New Zealand during the LGM, then the two proxies are easily reconciled. We thus contend that the beetle evidence, rather than being in conflict, is strongly supportive of the broad pollen and macrofossil conclusions of:

- widespread survival of forest, albeit in small and scattered patches with larger remnants close to the LGM coastline on coastal hills;

- abundant tall shrubland in the North Island and relatively less in the south;

- grassland throughout, patchy in the far north, but becoming more extensive in the south;

- very open herbaceous and low-growing shrub communities in many parts of the eastern South Island.

\section{Acknowledgements}

We thank Simon Haberle (editor), Nick Porch and an anonymous referee for their helpful comments on a draft of this contribution.

\section{References}

Alloway, B.V., D.J. Lowe, D.J.A. Barrell, R.M. Newnham, P.C. Almond, P.C. Augustinus, N.A.N. Bertler, L. Carter, N.J. Litchfield, M.S. McGlone, J. Shulmeister, M.J. Vandergoes, P.W. Williams and N.I. Members 2007. Towards a climate event stratigraphy for New Zealand over the past 30000 years (NZ-INTIMATE project). Journal of Quaternary Science 22(1):9-35. 
Alloway, B.V., R.B. Stewart, V.E. Neall and C.G. Vucetich 1992. Climate of the Last Glaciation in New Zealand, based on aerosolic quartz influx in an andesitic terrain. Quaternary Research 38(2):170-179.

Bannister, P. 2003. Are frost hardiness ratings useful predictors of frost damage in the field? A test using damage records from the severe frost in South Otago and Southland, New Zealand, July 1996. New Zealand Journal of Botany 41(3):555-569.

Bannister, P. 2007. A touch of frost? Cold hardiness of plants in the Southern Hemisphere. New Zealand Journal of Botany 45(1):1-33.

Barrows, T.T., S. Juggins, P. De Deckker, E. Calvo and C. Pelejero 2007. Long-term sea surface temperature and climate change in the Australian-New Zealand region. Paleoceanography 22(2).

Bennett, K. D. and J. Provan 2008. What do we mean by 'refugia'? Quaternary Science Reviews 27(27-28):2449-2455.

Burge, P.I. and J. Shulmeister 2007. Re-envisioning the structure of last glacial vegetation in New Zealand using beetle fossils. Quaternary Research 68(1):121-132.

Carter, L., H.L. Neil and L. Northcote 2002. Late Quaternary ice-rafting events in the SW Pacific Ocean, off eastern New Zealand. Marine Geology 191(1-2):19-35.

Crundwell, M., G. Scott, T. Naish and L. Carter 2008. Glacial-interglacial ocean climate variability from planktonic foraminifera during the Mid-Pleistocene transition in the temperate Southwest Pacific, ODP Site 1123. Palaeogeography Palaeoclimatology Palaeoecology 260(1-2):202-229.

Dodson, J.R., N.J. Enright and R.F. McLean 1988. A late Quaternary vegetation history for far northern New Zealand. Journal of Biogeography 15(4):647-656.

Drost, F., J. Renwick, B. Bhaskaran, H. Oliver and J. McGregor 2007. Simulation of New Zealand's climate using a high-resolution nested regional climate model. International Journal of Climatology 27(9):1153-1169.

Elliot, M.B. 1998. Late Quaternary pollen records of vegetation and climate change from Kaitaia Bog, far northern New Zealand. Review of Palaeobotany and Palynology 99(2):189-202.

Fraser, C.I., R. Nikula, H.G. Spencer and J.M. Waters 2009. Kelp genes reveal effects of subantarctic sea ice during the Last Glacial Maximum. Proceedings of the National Academy of Sciences of the United States of America 106(9):3249-3253.

Harle, K.J., A.P. Kershaw and E. Clayton 2004. Patterns of vegetation change in southwest Victoria (Australia) over the last two glacial/interglacial cycles: evidence from Lake Wangoom. Proceedings of the Royal Society of Victoria 116:105-137.

Ladeau, S.L. and J.S. Clark 2006. Pollen production by Pinus taeda growing in elevated atmospheric CO2. Functional Ecology 20(3):541-547.

Lancashire, A.K., J.R. Flenley and M.A. Harper 2002. Late glacial beech forest: an 18,0005000-BP pollen record from Auckland, New Zealand. Global and Planetary Change 33:315-327.

Lees, C.M., V.E. Neall and A.S. Palmer 1998. Forest persistence at coastal Waikato, 24000 years BP to present. Journal of the Royal Society of New Zealand 28(1):55-81.

Lowe, D.J., P.A.R. Shane, B.V. Alloway and R.M. Newnham 2008. Fingerprints and age models for widespread New Zealand tephra marker beds erupted since 30,000 years ago: a framework for NZ-INTIMATE. Quaternary Science Reviews 27(1-2):95-126.

Marra, M. and R.A.B. Leschen 2004. Late Quaternary paleoecology from fossil beetle communities in the Awatere Valley, South Island, New zealand. Journal of Biogeography 31(4):571-586.

Marra, M.J., B.V. Alloway and R.M. Newnham 2006. Paleoenvironmental reconstruction of a well-preserved Stage 7 forest sequence catastrophically buried by basaltic eruptive deposits, northern New Zealand. Quaternary Science Reviews 25(17-18):2143-2161. 
McGlone, M.S. 1980. Late Quaternary Vegetation History of central North Island, New Zealand, University of Canterbury.

McGlone, M.S. 1982. Modern pollen rain, Egmont National Park, New Zealand. New Zealand Journal of Botany 20(3):253-262.

McGlone, M.S. 1985. Plant biogeography and the late Cenozoic history of New Zealand. New Zealand Journal of Botany 23(4):723-749.

McGlone, M.S. 2001a. A late Quaternary pollen record from marine core P69, southeastern North Island, New Zealand. New Zealand Journal of Geology and Geophysics 44(1):69-77.

McGlone, M.S. 2001b. The origin of the indigenous grasslands of southeastern South Island in relation to pre-human woody ecosystems. New Zealand Journal of Ecology 25(1):1-15.

McGlone, M.S. 2002a. A Holocene and latest Pleistocene pollen record from Lake Poukawa, Hawke's Bay, New Zealand. Global and Planetary Change 33(3-4):283-299.

McGlone, M.S. 2002b. The late quaternary peat, vegetation and climate history of the southern oceanic islands of New Zealand. Quaternary Science Reviews 21(4-6):683-707.

McGlone, M.S. 2009. Postglacial history of New Zealand wetlands and implications for their conservation. New Zealand Journal of Ecology 33(1):1-23.

McGlone, M.S. and J.L. Bathgate 1983. Vegetation and climate history of the Longwood Range, South Island, New Zealand, 12,000 BP to the present. New Zealand Journal of Botany 21(3):293-315.

McGlone, M.S. and C.D. Meurk 2000. Modern pollen rain, subantarctic Campbell Island, New Zealand. New Zealand Journal of Ecology 24(2):181-194.

McGlone, M.S. and N.T. Moar 1997. Pollen-vegetation relationships on the subantarctic Auckland Islands, New Zealand. Review of Palaeobotany and Palynology 96(3-4):317-338.

McGlone, M.S. and N.T. Moar 1998. Dryland Holocene vegetation history, Central Otago and the Mackenzie Basin, South Island, New Zealand. New Zealand Journal of Botany 36(1):91-111.

McGlone, M.S. and V.E. Neall 1994. The late Pleistocene and Holocene vegetation history of Taranaki, North Island, New Zealand. New Zealand Journal of Botany 32(3):251-269.

McGlone, M.S., V.E. Neall and B.D. Clarkson 1988. The effect of recent volcanic events and climatic changes on the vegetation of Mt Egmont (Mt Taranaki), New Zealand. New Zealand Journal of Botany 26(1):123-144.

McGlone, M.S., V.E. Neall and B.J. Pillans 1984. Inaha terrace deposits - a late Quaternary terrestrial record in south Taranaki, New Zealand. New Zealand Journal of Geology and Geophysics 27(1):35-49.

McGlone, M.S., C.S. Nelson and T.M. Hume 1978. Palynology, age and environmental significance of some peat beds in the Upper Pleistocene Hinuera Formation, south Auckland, New Zealand. Journal of the Royal Society of New Zealand 8(4):385-393.

McGlone, M.S., C.S. Nelson and A.J. Todd 1984. Vegetation history and environmental significance of pre-peat and surficial peat deposits at Ohinewai, lower Waikato lowland. Journal of the Royal Society of New Zealand 14(3):233-244.

McGlone, M.S., M.J. Salinger and N.T. Moar 1993. Palaeovegetation studies of New Zealand's climate since the Last Glacial Maximum. In H. E. Wright, J. E. Kutzbach, T. Webb III, W. F. Ruddiman, F. A. Street-Perrrott and P.J. Bartlein (eds) Global Climates since the Last Glacial Maximum, pp 294-317. Minneapolis: University of Minnnesota Press.

McGlone, M.S. and W.W. Topping 1983. Late Quaternary vegetation, Tongariro region, central North Island, New Zealand. New Zealand Journal of Botany 21(1):53-76.

Mix, A.C., E. Bard and R. Schneider 2001. Environmental processes of the ice age: land, oceans, glaciers (EPILOG). Quaternary Science Reviews 20(4):627-657.

Moar, N., R.P. Suggate and C. Burrows 2008. Environments during the Kaihinu Interglacial and Otira Glaciation, coastal north Westland, New Zealand. New Zealand Journal of Botany 46(1):49-63. 
Moar, N.T. 1980. Late Otiran and early Aranuian grassland in central South Island. New Zealand Journal of Ecology 3:4-12.

Moar, N.T. and R.P. Suggate 1979. Contributions to the Quaternary history of the New Zealand flora 8. Interglacial and glacial vegetation in the Westport District, South Island. New Zealand Journal of Botany 17(3):361-387.

Moar, N.T. and R.P. Suggate 1996. Vegetation history from the Kaihinu (last) interglacial to the present, west coast, South Island, New Zealand. Quaternary Science Reviews 15(56):521-547.

Molloy, B.P. J., C.J. Burrows, J.E. Cox, J.A. Johnson and P. Wardle 1963. Distribution of subfossil remains in eastern South Island, New Zealand. New Zealand Journal of Botany 1:68-77.

Neall, V.E. 1979. Sheets P19, P20, \& P21, New Plymouth, Egmont, and Manaia. In Geological Map of New Zealand 1:50 000. 1 ed. Wellington: New Zealand Geological Survey, DSIR.

Newnham, R.M. 1992. 30,000 year pollen, vegetation and climate record from Otakairangi (Hikurangi), Northland, New Zealand Journal of Biogeography 19(5):541-554.

Newnham, R.M., D.N. Eden, D.J. Lowe and C.H. Hendy 2003. Rerewhakaaitu Tephra, a land-sea marker for the Last Termination in New Zealand, with implications for global climate change. Quaternary Science Reviews 22(2-4):289-308.

Newnham, R.M., D.J. Lowe, T. Giles and B.V. Alloway 2007. Vegetation and climate of Auckland, New Zealand, since ca. 32000 cal. yr ago: support for an extended LGM. Journal of Quaternary Science 22(5):517-534.

Newnham, R.M., D.J. Lowe and J.D. Green 1989. Palynology, vegetation and climate of the Waikato lowlands, North Island, New Zealand, since c. 18,000 years ago. Journal of the Royal Society of New Zealand 19(2):127-150.

Newnham, R.M., D.J. Lowe and P.W. Williams 1999. Quaternary environmental change in New Zealand: a review. Progress in Physical Geography 23(4):567-610.

Newnham, R.M., M.J. Vandergoes, C.H. Hendy, D.J. Lowe and F. Preusser 2007. A terrestrial palynological record for the last two glacial cycles from southwestern New Zealand. Quaternary Science Reviews 26(3-4):517-535.

Osmaston, H.A. 2006. Should Quaternary sea-level changes be used to correct glacier ELAs, vegetation belt altitudes and sea level temperatures for inferring climate changes? Quaternary Research 65(2):244-251.

Pelejero, C., E. Calvo, T.T. Barrows, G.A. Logan and P. De Deckker 2006. South Tasman Sea alkenone palaeothermometry over the last four glacial/interglacial cycles. Marine Geology 230(1-2):73-86.

Pillans, B., M. McGlone, A. Palmer, D. Mildenhall, B. Alloway and G. Berger 1991. The Last Glacial Maximum in central and southernmost North Island, New Zealand a paleoenvironmental reconstruction using the Kawakawa Tephra Formation as a chronostratigraphic marker. Palaeogeography, Paleoclimatology, Palaeoecology 101:283-304.

Pullar, W.A. and R.N. Patel 1972. Identification of tree stumps and driftwood associated with tephra layers in alluvium, peat, and dune sands. New Zealand Journal of Botany 10:605-614.

Randall, P.M. 1990. A Study of modern pollen deposition, Southern Alps, South Island, New Zealand. Review of Palaeobotany and Palynology 64:263-272.

Rogers, C.A., P.M. Wayne, E.A. Macklin, M.L. Muilenberg, C.J. Wagner, P.R. Epstein and F.A. Bazzaz 2006. Interaction of the onset of spring and elevated atmospheric $\mathrm{CO} 2$ on ragweed (Ambrosia artemisiifolia L.) pollen production. Environmental Health Perspectives 114(6):865-869.

Sandiford, A., R. Newnham, B. Alloway and J. Ogden 2003. A 28,000-7600 cal yr BP pollen record of vegetation and climate change from Pukaki Crater, northern New Zealand. Palaeogeography Palaeoclimatology Palaeoecology 201(3-4):235-247. 
Soons, J.M. and C.J. Burrows 1978. Dates for Otiran deposits, including plant microfossils and macrofossils, from Rakaia Valley. New Zealand Journal of Geology and Geophysics 21:607-615.

Sugita, S. 1994. Pollen Representation of Vegetation in Quaternary Sediments: Theory and Method in Patchy Vegetation. Journal of Ecology 82(4):881-897.

Turney, C.S.M., J.E. Hunt and C. Burrows 2002. Deriving a consistent delta C-13 signature from tree canopy leaf material for palaeoclimatic reconstruction. New Phytologist 155(2):301-311.

Vandergoes, M.J., R.M. Newnham, F. Preusser, C.H. Hendy, T.V. Lowell, S.J. Fitzsimons, A.G. Hogg, H.U. Kasper and C. Schluchter 2005. Regional insolationforcing of late Quaternary climate change in the Southern Hemisphere. Nature 436(7048):242-245.

Wardle, P. 1985. New Zealand timberlines. 3. A synthesis. New Zealand Journal of Botany 23:263-271.

Wardle, P. 2001. Holocene forest fires in the upper Clutha district, Otago, New Zealand. New Zealand Journal of Botany 39(3):523-542.

Wilmshurst, J.M., M.S. McGlone, J.R. Leathwick and R.M. Newnham 2007. A predeforestation pollen-climate calibration model for New Zealand and quantitative temperature reconstructions for the past 18000 years BP. Journal of Quaternary Science 22(5):535-547.

Woodward, C.A. and J. Shulmeister 2007. Chironomid-based reconstructions of summer air temperature from lake deposits in Lyndon Stream, New Zealand spanning the MIS 3/2 transition. Quaternary Science Reviews 26(1-2):142-154. 